\title{
Intake and digestibility of crossbred goats finished on caatinga grassland receiving feed supplementation during dry season ${ }^{1}$
}

\author{
Consumo e digestibilidade em caprinos mestiços terminados em pasto de caatinga \\ recebendo suplementação alimentar durante a estação seca
}

\author{
SILVA, Daniel Cézar da ${ }^{2}$; GUIM, Adriana ${ }^{3}$; SANTOS, Gladston Rafael de Arruda ${ }^{4}$; \\ SOUZA, Evaristo Jorge de Oliveira ; URBANO, Stela Antas ${ }^{3}$; MESQUITA, Fernando \\ Lucas Torres de ${ }^{6}$; LAFAYETTE, Elizabeth Almeida ${ }^{7}$
}

\footnotetext{
${ }^{1}$ Parte da Tese de Doutorado do primeiro autor, financiada pela FACEPE e executada pelo acordo UFRPE / IPA. ${ }^{2}$ Instituto Federal de Educação, Ciência e Tecnologia da Paraíba, São Gonçalo, Sousa, Paraíba, Brasil.

${ }^{3}$ Universidade Federal Rural de Pernambuco, Departamento de Zootecnia, Recife, Pernambuco, Brasil.

${ }^{4}$ Universidade Federal de Sergipe, Departamento de Zootecnia, Aracaju, Sergipe, Brasil.

${ }^{5}$ Universidade Federal Rural de Pernambuco, Departamento de Zootecnia, Serra Talhada, Pernambuco, Brasil.

${ }^{6}$ Instituto Agronômico de Pernambuco, Sertânia, Pernambuco, Brasil.

${ }^{7}$ Universidade Federal de Pernambuco, Departamento de Antibióticos, Recife, Pernambuco, Brasil

*Endereço para correspondência: danielcezar.s@ig.com.br
}

\section{SUMMARY}

It was evaluated the effect of feed supplementation at $0.4 ; 0.8$ and $1.2 \%$ of body weight (BW) on intake and digestibility of crossbred goats finished on caatinga, in relation to crossbred goats not supplemented $(0.0 \%$ of BW). Thirty-two crossbred, Anglo-Nubian goats were used, eight months old and with body weight of $18 \pm 2.5 \mathrm{~kg}$, organised into randomised blocks, which were kept on 37 hectares of caatinga from 7 $\mathrm{h}$ to $16 \mathrm{~h}$. Intake of dry matter, organic matter, crude protein, ether extract, neutral and acid detergent fibre, total carbohydrates and total digestible nutrients was influenced $(\mathrm{P}<0.05)$ by the levels of feed supplementation, with linear increases of $202.31 ; 179.42 ; 25.05 ; 11.83 ; 35.79$; 12.27; 142.63 and $166.79 \mathrm{~g}$ animal $^{-1}$ day $^{-1}$ respectively. There was a substitution effect $(\mathrm{P}<0.05)$ on dry matter intake when using feed supplementation at $0.7 \%$ BW. Feed supplementation resulted in positive linear effect $(\mathrm{P}<0.05)$ for digestibility of dry matter, organic matter, crude protein, ether extract, total carbohydrates, total digestible-nutrient content and digestible energy, with an increase of 17.15;
$16.64 ; 19.07 ; 44.74 ; 15.15$ and $17.56 \%$ for dry matter, and 0.69 Mcal $\mathrm{kg}^{-1}$ of dry matter respectively. Final body weight, total gain and average daily gain, showed a linear increase $(\mathrm{P}<.005)$ of $2.60,3.09$ and $0.036 \mathrm{~kg}$ per percentage point of each additional level of supplement. Feed supplementation increases the intake and digestibility of total dry matter and nutrients, a fact that makes greater performance possible, and recommends use up to a level of $0.7 \%$ BW to avoid any substitution effect.

Keywords: feeding strategy, goat livestock, native pasture, nutrient intake

\section{RESUMO}

Avaliou-se o efeito da suplementação alimentar 0,$4 ; 0,8$ e $1,2 \%$ do peso corporal (PC) sobre o desempenho de caprinos mestiços terminados em pasto de caatinga, em relação a caprinos mestiços não suplementados $(0,0 \%$ do PC). Utilizou-se 32 caprinos machos castrados, mestiços Anglonubiana, com oito meses de idade e peso corporal médio de $18 \pm 2,5 \mathrm{~kg}$, distribuídos em 
delineamento de blocos casualizados, mantidos em 37 hectares de caatinga, das $7 \mathrm{~h}$ às $16 \mathrm{~h}$. $\mathrm{O}$ consumo de matéria seca, matéria orgânica, proteína bruta, extrato etéreo, fibra em detergente neutro e ácido, carboidrato totais e nutrientes digestíveis totais foram influenciados $(\mathrm{P}<0,05)$ pelos níveis de suplementação alimentar, com acréscimos lineares de, 202,31; 179,42; 25,05; 11,$83 ; 35,79 ; 12,27,142,63$ e $166,79 \mathrm{~g} \mathrm{animal}^{-1}$ $\mathrm{dia}^{-1}$, respectivamente. Houve efeito substitutivo $(\mathrm{P}<0,05)$ do consumo de matéria seca a partir de $0,7 \%$ PC. A suplementação alimentar resultou em efeito linear positivo $(\mathrm{P}<0,05)$ sobre a digestibilidade da matéria seca, matéria orgânica, proteína bruta, extrato etéreo, carboidratos totais, teor de nutrientes digestíveis totais e energia digestível, com acréscimos de, 17,15; 16,64; 19,$07 ; 44,74 ; 15,15$ e $17,56 \%$ na matéria seca; e $0,69 \mathrm{Mcal} \mathrm{kg}^{-1}$ de matéria seca, respectivamente. $\mathrm{O}$ peso corporal final, ganho total e ganho médio diário, elevaram-se linearmente $(\mathrm{P}<0,05)$ em 2,60; 3,09 e $0,036 \mathrm{~kg}$ por unidade percentual do nível de suplementação. A suplementação alimentar eleva o consumo e digestibilidade de matéria seca total e dos nutrientes, fato que possibilita maior desempenho, com recomendação para utilização até o nível de $0,7 \%$ PC para evitar efeito de substituição.

Palavras-chave: caprinocultura, consumo de nutrientes, estratégia alimentar, pasto nativo

\section{INTRODUCTION}

The caatinga biome is a plant complex abundant in woody, shrubby and herbaceous species, with multiple use, and great socio economic value to population of this semiarid region, such as: potential animal feed, alternative medicine, using fruits, shell and roots, natural resources exploration and crop subsistence.

Most important of these is goat farming, according to IBGE (2009) there are $8.303,143$ goats in the Northeast, corresponding to $90.6 \%$ of the total for Brazil, as this offers a good alternative choice of employment and income, thanks to the production of food which is high in biological value (milk, meat and offal), as well as skin products (COSTA et al., 2008).

In spite of these aspects, goats in the Northeast still have low production rates, due to production systems which are characterised by the absence or inappropriate use of technology related to animal nutrition. Together with these factors, a diet based only on caatinga grassland imposes some limitations, since while the dry period is established, lasting eight months on average, the availability of biomass and nutrients for the flocks is reduced.

Faced with this scenario, it is necessary to adopt strategies aimed at minimising the impact of this variation on the performance of the goat herds, especially feed supplementation. According to Andrade et al. (2010), supplemental feeding is a strategy, which is necessary in production systems of the Northeast, and can take the form of energy and/or protein supplements and inorganic supplements.

In addition to supplying nutrients, supplementation may be associated with the provision of additional sources of roughage, and based mainly on the use of native forage from xerophilic crops.

When evaluating supplementation levels of 0.0 to $1.5 \%$ of body weight for $\mathrm{F} 1$ goats, Carvalho Júnior et al. (2011) obtained a positive linear increase $(\mathrm{P}<.01)$ for dry matter intake and average total gain, with increases of $257.15 \mathrm{~g} \mathrm{animal}^{-1}$ day $^{-1}$ and $2.88 \mathrm{~kg}$ respectively.

Despite the positive aspects of rational feed supplementation referred to above, this is a little-used feeding strategy in livestock farming of the Northeast. There is a need for studies aimed at evaluating the responses of this practice in goats kept 
on pasture with a variety of vegetation, such as caatinga.

It was evaluated the effect of proteinenergy feed supplementation on the intake and digestibility of crossbred goats finished on caatinga grassland during the dry season.

\section{MATERIALS AND METHODS}

The survey was carried at the Sertânia Experimental Station of the Pernambuco Institute of Agronomy (IPA), located at $08^{\circ} 04^{\prime} 25^{\prime \prime} \mathrm{S}$ and $37^{\circ} 15^{\prime} 52^{\prime \prime} \mathrm{W}$, in the micro-region of Sertão do Moxotó, in the municipality of Sertânia, the State of Pernambuco. The ecosystem is of caatinga and the climate is type BShW, semi-arid, having distinct wet and dry seasons. The mean temperature for the evaluation period was $25.1{ }^{\circ} \mathrm{C}$ with an accumulated rainfall of 71.05 (LAMEPE, 2011).

The research took 101 days, including 17 days of adaptation to experimental conditions and 84 days of data collection. The goats were kept under continuous grazing in an experimental area of 37 hectares with a hyperxerophilic caatinga vegetation of dense trees and shrubs.

The goats were allowed access to the pasture from $7 \mathrm{~h}$ to $16 \mathrm{~h}$, when they were rounded up, taken to the experimental shed and housed in individual stalls where they received the feed supplement. Each stall was $1.0 \times 1.40 \mathrm{~m}$ in size, covered, had a floor of beaten earth, and was equipped with a drinking trough, salt dispenser and feeder.

The effects of protein-energy feed supplementation were evaluated at levels of $0.4 ; 0.8$ and $1.2 \%$ of body weight (\%BW) based on dry matter, on the intake and digestibility of crossbred goats finished on caatinga, in relation to crossbred goats not supplemented $(0,0 \%$ of BW). These levels were specified, considering the results for chemical composition and in situ degradability obtained by Santos et al. (2009) in the same experimental area used in this research.

The feed supplement consisted of forage palm (Nopalea cochenillifera (L.) SalmDyck), processed in a cactus grinding machine, concentrated and formulated according to the nutritional requirements recommended by NRC (2007) to meet a minimum daily average gain of $50 \mathrm{~g}$ (Tables 1 and 2). It should be noted that the forage palm was ground up immediately prior to feeding, and homogenised into the pre-mixture of energy-protein concentrates.

The research was carried out on 32 castrated male, crossbred Anglo-Nubian goats, with an average initial age of eight months, and a mean body weight of $18 \pm$ $2.5 \mathrm{~kg}$, which were weighed before the start of the experimental period after fasting for 16 hours, and were then distributed following a random block design across four treatments (supplementation levels) with eight replications (goats).

Performance was accompanied by weighing, which was carried out at intervals of seven days and preceded by a 12 hours period of fasting before the animals were given access to the caatinga pasture. Data for weight gain were also used for weekly adjustments to the supply of feed supplement, which were based on body weight. 
Rev. Bras. Saúde Prod. Anim., Salvador, v.17, n.3, p.484-496 jul./set., 2016

Table 1. Bromatological composition of supplement ingredients

\begin{tabular}{lccccc}
\hline \multirow{2}{*}{ Nutrient } & \multicolumn{3}{c}{ Ingredient } \\
\cline { 2 - 6 } & $\begin{array}{c}\text { Forage } \\
\text { palm }\end{array}$ & $\begin{array}{c}\text { Ground } \\
\text { maize }\end{array}$ & $\begin{array}{c}\text { Wheat } \\
\text { bran }\end{array}$ & $\begin{array}{c}\text { Soybean } \\
\text { meal }\end{array}$ & Cottonseed \\
\hline Dry Matter (DM), \% & 14.26 & 88.48 & 86.59 & 89.55 & 91.31 \\
\hline \% DM & & & & & \\
\hline Organic Matter & 86.08 & 98.03 & 94.44 & 93.27 & 96.30 \\
Ash & 13.92 & 1.97 & 5.56 & 6.73 & 3.70 \\
Crude Protein & 2.98 & 11.01 & 19.73 & 52.28 & 24.37 \\
Ether extract & 0.78 & 6.28 & 4.07 & 3.79 & 16.84 \\
Total Carbohydrates ${ }^{1}$ & 82.68 & 80.74 & 70.64 & 37.20 & 55.09 \\
Ash-corrected neutral detergent & 18.4 & 22.74 & 40.67 & 21.72 & 49.35 \\
fibre & 8.84 & 2.67 & 11.76 & 6.52 & 11.76 \\
Acid detergent fibre & & & & & \\
\hline
\end{tabular}

${ }^{a}$ Calculated as per Sniffen et al. (1992).

Table 2. Centesimal and bromatological composition of the supplement

\begin{tabular}{|c|c|}
\hline \multirow{2}{*}{ Ingredient/nutrient } & Centesimal composition \\
\hline & $\mathrm{g} \mathrm{kg}^{-1}$ dry matter \\
\hline Forage palm & 50.00 \\
\hline Ground maize & 16.14 \\
\hline Wheat bran & 9.94 \\
\hline Cottonseed & 17.22 \\
\hline Soybean meal & 5.70 \\
\hline \multirow[t]{2}{*}{ Vitamin-mineral nucleus ${ }^{\mathrm{a}}$} & 1.00 \\
\hline & Bromatological composition \\
\hline Dry Matter (DM), \% & 2185 \\
\hline$\% \mathrm{DM}$ & 21.85 \\
\hline Organic matter & 89.18 \\
\hline Ash & 10.82 \\
\hline Crude protein & 12.57 \\
\hline Ether extract & 5.79 \\
\hline Total carbohydrates ${ }^{\mathrm{b}}$ & 71.07 \\
\hline Ash-corrected neutral detergent fibre & 24.04 \\
\hline Acid detergent fibre & 10.87 \\
\hline Hemicellulose & 13.21 \\
\hline Cellulose & 9.49 \\
\hline Lignin & 0.57 \\
\hline In vitro digestibility of DM \% & 78.56 \\
\hline
\end{tabular}


To estimate intake and digestibility, faecal dry matter production (FDMP) was used and obtained by using a LIPE $®$ external indicator (Modified and enriched hydroxyphenylpropane: P2S2, Florestal, Minas Gerais, Brazil), in daily, single doses of $250 \mathrm{mg}$, given orally from the seventh day of each experimental period. The faeces were collected for five consecutive days directly from the rectal ampulla, before allowing the animals access to the pasture (SALIBA et al., 2014).

Samples of extrusa (caatinga pasture) were obtained using an without defined breed rumen-fistulated, castrated, male goat, with a body weight of $45 \mathrm{~kg}$, following a methodology proposed by Santos et al. (2008), with two collections in each experimental period, on alternate days, and always at $8 \mathrm{~h}$ and $14 \mathrm{~h}$.

The samples of faeces and extrusa made up composite samples for the four experimental periods, and were processed to determine the levels of dry matter
(DM), mineral matter (MM), crude protein $(\mathrm{CP})$ and ether extract (EE), neutral detergent fibre (NDF), acid detergent fibre (ADF), hemicellulose (HEM), cellulose (CEL) and lignin (LIG), as per methodologies described by Gomes \& Oliveira (2011). The samples were evaluated at the Laboratory for Animal Nutrition of the Federal Rural University of Pernambuco. The bromatological composition of the caatinga pasture (extrusa) is presented in Table 3 .

To estimate the intake of nutrients from the pasture, it was use in association LIPE ${ }^{\circledR}$ a indigestible dry matter (DMi) was used as an internal marker, obtained after incubation for 288 hours in the rumen of an adult water buffalo, adopting for procedures of ruminal incubation: $1 \mathrm{~g}$ samples of extrusa, faeces and supplement, ground down to $2 \mathrm{~mm}$ and packed in $4 \times 5 \mathrm{~cm}$ bags of non-woven textile (NWT with a grammage of $100 \mathrm{~g}$ $\mathrm{m}^{2-1}$ ) according Soares et al. (2011).

Tabela 3. Bromatological composition of the caatinga pasture (extrusa)

\begin{tabular}{lc}
\hline & Bromatological composition \\
\hline Dry Matter (DM), \% & 25.29 \\
\% DM & 91.34 \\
Organic matter & 8.67 \\
Ash & 12.27 \\
Crude protein & 3.39 \\
Ether extract & 75.67 \\
Total carbohydrates ${ }^{\mathrm{a}}$ & 57.02 \\
Ash-corrected neutral detergent fibre & 33.50 \\
Acid detergent fibre & 21.75 \\
Cellulose & 12.26 \\
Lignin & 44.06 \\
NDIP (\% of CP) & 32.34 \\
ADIP (\% of CP) & 45.66 \\
In vitro digestibility of DM \% & 33.69 \\
Total digestible nutrients\% & \\
\hline Calculed as per Sniffen
\end{tabular}

\footnotetext{
${ }^{\mathrm{a}}$ Calculated as per Sniffen et al. (1992).
} 
From the values for FDMP and DMi, the day $^{-1}$ ) as per the equation described by total DM intake was estimated (DMI kg Santana et al. (2010):

$$
\begin{aligned}
D M I & =\frac{\left\{\left[\text { FDMP }\left(\mathrm{kg} \mathrm{day}^{-1}\right) \times \% D M i_{\text {Faeces }}\right]-\left[D M i_{\text {Supplement }}\left(\mathrm{kg} \mathrm{day}^{-1}\right)\right]\right\}}{\% D M i_{\text {Extrusa }}} \\
& +D M_{\text {Supplement intake }}\left(\mathrm{kg} \mathrm{day}^{-1}\right)
\end{aligned}
$$

The apparent digestibility coefficients (DC\%) of DM, OM, PB, EE, NDF, ADF obtained from the data for FDMP and and total carbohydrates (TC) were

$$
D C \%=\frac{\text { Intake nutrient }\left(\mathrm{g} \mathrm{animal}^{-1} \text { day }^{-1}\right)-\text { Faecal nutrient }_{\left(\mathrm{g} \mathrm{animal}^{-1} \text { day }^{-1}\right)}}{\text { Intake nutrient }\left(\text { g animal }^{-1} \text { day }^{-1}\right)} \times 100
$$

The coefficient of substitution for the dry matter intake (DMI) from the forage by

the feed supplement was estimated using the formula:

$$
\begin{aligned}
& \text { DMI }\left(\mathrm{kg} \mathrm{day}^{-1}\right) \text { unsupplemented goats - } \\
& \text { Coefficient of substitution } \%=\frac{D M I\left(\mathrm{kgday}^{-1}\right) \text { supplemented goats }}{D M I\left(\mathrm{~kg} \mathrm{day}^{-1}\right) \text { feed supplement }} \times 100
\end{aligned}
$$

A randomised block design was adopted, of four treatments (levels of supplementation), eight replications (goats) and four blocks (intervals for body weight, 14 to 15,16 to 17,18 to 19 e 20 to $21 \mathrm{~kg}$ ). The data were analysed with the PROC MEANS procedure of the SAS (2001) statistical software, using descriptive statistics for the mean, standard deviation and coefficient of variation. Linear and quadratic regression analysis was also carried out using the PROC GLM procedure, following the method of least squares, and adopting a significance level of .05 for model selection, together with the regression coefficients. Correlation analysis was carried out following the PROC CORR procedure, adopting a significance level of .05 .

\section{RESULTS AND DISCUSSION}

Feed supplementation influenced the intake of neutral detergent fibre (NDFI), acid detergent fiber (ADFI) and lignin (LIGI) $(\mathrm{P}<.05)$ in $\mathrm{g}$ animal ${ }^{-1}$ day $^{-1}$; however values expressed in $\% \mathrm{BW}$ and $\mathrm{g}$ $\operatorname{kg~} 0.75^{-1}$ were similar $(\mathrm{P}>.05)$, with mean values of $1.03 \% \mathrm{BW}$ and $21.5 \mathrm{~g} \mathrm{~kg} 0.75^{-1}$ for NDFI, $0.58 \% \mathrm{BW}$ and $12.97 \mathrm{~g} \mathrm{~kg} 0.75$ ${ }^{-1}$ for ADFI, and $0.19 \% \mathrm{BW}$ and $3.91 \mathrm{~g} \mathrm{~kg}$ $0.75^{-1}$ for LIGI (Table 4).

The DMI presented a linear increase of $202.32 \mathrm{~g} \mathrm{animal}^{-1}$ day $^{-1}$ and $0.88 \% \mathrm{BW}$ per percentage point of added feed supplement, demonstrating the benefit of using this feeding strategy, which increased DMI from the total diet. 
Rev. Bras. Saúde Prod. Anim., Salvador, v.17, n.3, p.484-496 jul./set., $2016 \quad \underline{\text { http://www.rbspa.ufba.br }}$ ISSN 15199940 http://dx.doi.org/10.1590/S1519-99402016000300014

Tabela 4. Mean values and regression equations for the intake of dry matter and nutrients from diet in crossbred goats finished on a pasture of caatinga and receiving feed supplementation

\begin{tabular}{|c|c|c|c|c|c|c|}
\hline \multirow{2}{*}{ Unit } & \multicolumn{4}{|c|}{ Level of feed supplementation (\%BW) } & \multirow{2}{*}{ Regression equation } & \multirow{2}{*}{$\mathrm{CV}(\%)$} \\
\hline & 0.0 & 0.4 & 0.8 & 1.2 & & \\
\hline \multicolumn{7}{|c|}{ Dry matter intake } \\
\hline $\mathrm{g}$ animal $^{-1}$ day $^{-1}$ & 301.83 & 398.47 & 481.36 & 543.96 & 1 & 7.22 \\
\hline$\% \mathrm{BW}$ & 1.66 & 2.06 & 2.49 & 2.69 & 2 & 13.74 \\
\hline $\operatorname{g~kg~} 0.75^{-1}$ & 34.24 & 43.08 & 52.07 & 57.03 & 3 & 10.50 \\
\hline \multicolumn{7}{|c|}{ Organic matter intake } \\
\hline g animal $^{-1}$ day $^{-1}$ & 275.93 & 362.49 & 435.57 & 490.90 & 4 & 7.12 \\
\hline$\% \mathrm{BW}$ & 1.52 & 1.87 & 2.26 & 2.43 & 5 & 13.79 \\
\hline $\mathrm{g} \mathrm{kg} 0.75^{-1}$ & 31.31 & 39.19 & 47.12 & 51.46 & 6 & 10.60 \\
\hline \multicolumn{7}{|c|}{ Crude protein intake } \\
\hline $\mathrm{g} \mathrm{animal}^{-1}$ day $^{-1}$ & 37.21 & 49.45 & 59.45 & 67.28 & 7 & 7.61 \\
\hline$\% \mathrm{BW}$ & 0.21 & 0.25 & 0.31 & 0.33 & 8 & 13.65 \\
\hline $\operatorname{g~kg~} 0.75^{-1}$ & 4.23 & 5.34 & 6.42 & 7.05 & 9 & 10.53 \\
\hline \multicolumn{7}{|c|}{ Ether extract intake } \\
\hline $\mathrm{g} \mathrm{animal}^{-1}$ day $^{-1}$ & 10.10 & 15.10 & 20.16 & 24.19 & 10 & 8.39 \\
\hline$\% \mathrm{BW}$ & 0.06 & 0.08 & 0.10 & 0.12 & 11 & 12.10 \\
\hline $\mathrm{g} \mathrm{kg} 0.75^{-1}$ & 1.14 & 1.63 & 2.18 & 2.54 & 12 & 9.01 \\
\hline \multicolumn{7}{|c|}{ Neutral detergent fibre intake } \\
\hline $\mathrm{g}$ animal $^{-1}$ day $^{-1}$ & 171.38 & 194.75 & 210.61 & 213.81 & 13 & 6.25 \\
\hline$\% \mathrm{BW}$ & 0.94 & 1.01 & 1.10 & 1.06 & $\hat{\mathrm{y}}=1.03, \mathrm{~ns}^{\mathrm{a}}$ & 17.14 \\
\hline $\operatorname{g~kg~} 0.75^{-1}$ & 19.43 & 21.10 & 22.96 & 22.50 & $\hat{\mathrm{y}}=21.50, \mathrm{~ns}$ & 13.68 \\
\hline \multicolumn{7}{|c|}{ Acid detergent fibre intake } \\
\hline g animal $^{-1}$ day $^{-1}$ & 100.58 & 110.57 & 116.94 & 114.81 & 14 & 6.45 \\
\hline$\% \mathrm{BW}$ & 0.55 & 0.57 & 0.61 & 0.57 & $\hat{\mathrm{y}}=0.58, \mathrm{~ns}$ & 18.29 \\
\hline $\operatorname{g~kg~} 0.75^{-1}$ & 11.39 & 11.98 & 12.79 & 12.11 & $\hat{\mathrm{y}}=12.97, \mathrm{~ns}$ & 14.75 \\
\hline \multicolumn{7}{|c|}{ Total carbohydrate intake } \\
\hline $\mathrm{g}$ animal $^{-1}$ day $^{-1}$ & 228.61 & 297.92 & 356.01 & 399.42 & 15 & 7.01 \\
\hline$\% \mathrm{BW}$ & 1.26 & 1.54 & 1.84 & 1.98 & 16 & 13.93 \\
\hline g kg $0.75^{-1}$ & 25.94 & 32.21 & 38.52 & 41.87 & 17 & 10.68 \\
\hline \multicolumn{7}{|c|}{ Total digestible nutrient intake } \\
\hline g animal $^{-1}$ day $^{-1}$ & 101.48 & 172.29 & 245.12 & 299.59 & 18 & 12.90 \\
\hline$\% \mathrm{BW}$ & 0.57 & 0.88 & 1.26 & 1.47 & 19 & 12.85 \\
\hline $\operatorname{g~kg~} 0.75^{-1}$ & 11.62 & 18.56 & 26.30 & 31.25 & 20 & 10.91 \\
\hline \multicolumn{7}{|c|}{ Lignin intake } \\
\hline $\mathrm{g}$ animal $^{-1}$ day $^{-1}$ & 36.63 & 37.00 & 36.73 & 32.52 & 21 & 8.24 \\
\hline$\% \mathrm{BW}$ & 0.20 & 0.19 & 0.19 & 0.16 & $\hat{\mathrm{y}}=0.19, \mathrm{~ns}$ & 21.41 \\
\hline $\operatorname{g~kg~} 0.75^{-1}$ & 4.14 & 4.01 & 4.05 & 3.45 & $\hat{\mathrm{y}}=3.91, \mathrm{~ns}$ & 17.87 \\
\hline
\end{tabular}

${ }^{\mathrm{a}}$ Not significant, $\mathrm{P}>.05$.

${ }^{1} \hat{y}=310.02+202.32 x, R^{2}=0.91 ; P<.001$

${ }^{2} \hat{y}=1.70+0.88 x, R^{2}=0.65 ; P<.0001$

${ }^{3} \hat{y}=35.00+19.35 x, R^{2}=0.78 ; P<.0001$

${ }^{4} \hat{y}=283.52+179.42 x, R^{2}=0.90 ; P<.0001$

${ }^{5} \hat{\mathrm{y}}=1.55+0.78 \mathrm{x}, \mathrm{R}^{2}=0.64 ; \mathrm{P}<.0001$

${ }^{6} \hat{\mathrm{y}}=32.01+17.10 \mathrm{x}, \mathrm{R}^{2}=0.76 ; \mathrm{P}<.0001$

${ }^{7} \hat{y}=38.31+25.05 x, R^{2}=0.89 ; P<.0001$

${ }^{8} \hat{y}=0.21+0.11 x, R^{2}=0.65 ; P<.0001$

${ }^{9} \hat{\mathrm{y}}=4.33+2.99 \mathrm{x}, \mathrm{R}^{2}=0.78 ; \mathrm{P}<.0001$

${ }^{10} \hat{\mathrm{y}}=10.29+11.83 \mathrm{x}, \mathrm{R}^{2}=0.94 ; \mathrm{P}<.0001$

${ }^{11} \hat{y}=0.056+0.055 x, R^{2}=0.85 ; P<.0001$

${ }^{12} \hat{\mathrm{y}}=1.16+1.86 \mathrm{x}, \mathrm{R}^{2}=0.91 ; \mathrm{P}<.0001$

${ }^{13} \hat{y}=176.17+35.79 x, R^{2}=0.65 ; P<.0001$

${ }^{14} \hat{y}=103.37+12.27 x, R^{2}=0.40 ; P<.003$

${ }^{15} \hat{\mathrm{y}}=234.91+142.63 \mathrm{x}, \mathrm{R}^{2}=0.90 ; \mathrm{P}<.0001$

${ }^{16} \hat{y}=1.29+0.61 x, R^{2}=0.61 ; P<.0005$

${ }^{17} \hat{y}=26.52+13.59 x, R 2=0.74 ; P<.0001$

${ }^{18} \hat{\mathrm{y}}=104.54+166.79 \mathrm{x}, \mathrm{R}^{2}=0.90 ; \mathrm{P}<.0001$

${ }^{19} \hat{\mathrm{y}}=0.58+0.77 \mathrm{x}, \mathrm{R}^{2}=0.88 ; \mathrm{P}<.0001$

${ }^{20} \hat{\mathrm{y}}=11.94+16.65 \mathrm{x}, \mathrm{R}^{2}=0.92 ; \mathrm{P}<.0001$

${ }^{21} \hat{y}=37.61-3.15 x, R^{2}=0.20 ; P<.04$

3.74

79

0.60 
The increase in DMI may be considered factor determining for animal performance, once promotes simultaneously increased on all nutrients intake with production gain. Evaluation complement to this research, Silva et al. (2014) found that feed supplementation of Anglonubian crossbred goats finished on caatinga raises the quantitative parameters of carcass associated with increases in muscle tissue, total fat and bones of the leg, recommending use of $1.2 \% \mathrm{BW}$.

Despite these results, increase in DMI from the total diet includes in part one of the objectives of feed supplementation, which is to enhance the DMI from pasture by virtue of an improvement in the conditions of rumen fermentation, due to the higher supply of nutrients for rumen microorganisms. However, some aspects of supplementation can lead to undesirable results, the substitution effect being important.
Regression analysis showed a quadratic effect $(\mathrm{P}<.05)$ from supplementation levels on the coefficient of substitution (Figure 1), and with equation derivation, the $0.7 \%$ BW limit for feed supplementation was found, at which the animals would start to consume the supplement rather than the pasture of caatinga.

Moreover, in relation to the coefficient of substitution, a large increase is seen when using feed supplementation at $1.2 \% \mathrm{BW}$, which is directly related to the dynamics of pasture, once, in situations where the availability of forage is low, grazing animals reach a maximum intake, and the supply of supplement has little effect on the intake of dry matter from the pasture. In addition, the increased availability of pasture, associated with the increased availability of nutrients, frequently results in substitution of intake, especially when using high levels of supplementation.

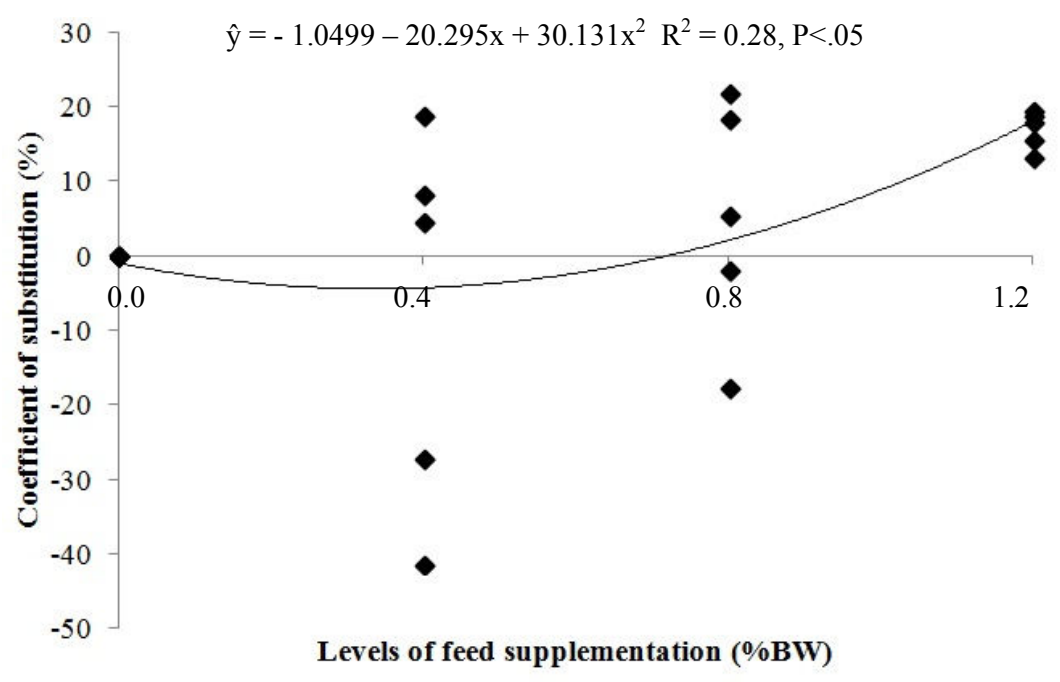

Figure 1. Regression for the coeficient of substitution (\%) of dry matter intake in crossbred goats finished on caatinga and receiving feed supplementation 
In this study therefore, the greatest substitution of dry matter intake, with supplementation at $1.2 \% \mathrm{BW}$, may be related to a possible increase in the availability of forage in the caatinga pasture during December, a result of more rainfall being recorded, which determined renewed growth of the vegetation associated with an improvement in nutritional value.

Feed supplementation resulted in a linear increase of $179.42 \mathrm{~g}$ animal $^{-1}$ day $^{-1}$ and $0.78 \% \mathrm{BW}$, for the OMI as a function of supplementation levels, which follows the trend seen for DMI (Table 4). This increase in OMI directly reflects the increased participation of the supplement in the composition of the intake, since from the supplementation level of $0.8 \%$ $\mathrm{BW}$, a decrease was observed in the OMI from the caatinga pasture.

There was a linear increase of $25.05 \mathrm{~g}$ animal $^{-1}$ day $^{-1}, 0.11 \% \mathrm{BW}$ and $2.99 \mathrm{~g} \mathrm{~kg}$ $0.75^{-1}$ due to feed supplementation for each additional level of supplementation above the CPI (Table 4). The rise in CPI in animals supplemented at 0.8 and $1.2 \%$ BW may be associated with a greater intake of dry matter from the supplement in those goats kept below these levels, resulting in a higher intake of protein, and confirmed by the positive correlation $\left(\mathrm{r}^{2}=\right.$ $0.73, \mathrm{P}<.05)$ between dry matter intake from the supplement and the total intake of crude protein.

Based on the nutritional requirements for crude protein intake in goats, as suggested by the NRC (2007), of 65.0g from DM animal $^{-1}$ day $^{-1}$, for an average gain of $50 \mathrm{~g}$ day $^{-1}$, it can be seen that feed supplementation levels of 0.4 and $0.8 \%$ BW were not sufficient to meet the nutritional requirements of the goats for consumption of this nutrient (Table 4). However, use of the highest level of feed supplementation resulted in the nutritional requirement being met, when the total crude protein intake is considered.

In general limitations on CPI are found in small ruminants finished on pasture of caatinga under different types of management, where the amounts of crude protein consumed are always below of the ewes requirements.

Their statement confirms the results of this study, in which goats finished solely on a pasture of caatinga showed a greater shortfall of protein intake, since the CPI in $\mathrm{g}$ animal $^{-1}$ day $^{-1}$ only represented $56.9 \%$ of the requirements for this nutrient according to the NRC (2007). A situation made worse when considering the levels of neutral detergent insoluble protein (NDIP) in caatinga pasture (extrusa): $44.05 \%$ from the dry matter (Table 3).

The NDFI in \%BW and $\mathrm{g} \mathrm{kg} 0.75^{-1}$ were not affected $(\mathrm{P}>.05)$ by the levels of feed supplementation, unlike the intake in $\mathrm{g}$ animal $^{-1}$ day $^{-1}$, which showed a linear increase of $35.79 \mathrm{~g}$ animal $^{-1}$ day $^{-1}$ per percentage point of added supplement.

It is a fact that the reduction in levels of fibre in diets for ruminants can adversely affect nutrient digestibility. In this study, feed supplementation altered the contribution of NDF from the roughage in the total diet, and resulted in a linear reduction in the proportion of NDF from the pasture, described by the equation $\hat{y}=$ $55.96-14.13 \mathrm{x}, \mathrm{R}^{2}=0.79, \mathrm{P}<.05(\hat{\mathrm{y}}=$ amount of NDF in the total diet; $x=$ level of feed supplementation), but such a reduction does not compromise the parameters for intake and digestibility of DM or of the other nutrients.

The TDNI increased linearly by $166.79 \mathrm{~g}$ animal $^{-1}$ day $^{-1}, 0.77 \%$ BW and $16.65 \mathrm{~g} \mathrm{~kg}$ $0.75^{-1}$ for each additional level of feed supplementation (Table 4). Relating this 
increase to the increase in TCI of $0.61 \%$ BW and $13.59 \mathrm{~g} \mathrm{~kg} 0.75^{-1}$ for each level of additional supplementation, it can be inferred that intake of potentially digestible nutrients was favoured, thus increasing the estimated levels of total digestible nutrients (TDN).
Feed supplementation resulted in a positive linear effect $(\mathrm{P}<.05)$ on the digestibility of dry matter (DMD) and organic matter (OMD), with an increase of 17.15 and $16.64 \%$ respectively, for each additional level of feed supplementation (Table 5).

Table 5. Mean values and regression equations for the digestibility of dry matter and nutrients from diet in crossbred goats finished on a pasture of caatinga and receiving feed supplementation

\begin{tabular}{|c|c|c|c|c|c|c|}
\hline \multirow{2}{*}{ Digestibility (\%) } & \multicolumn{4}{|c|}{ Level of supplementation (\%BW) } & \multirow{2}{*}{ Regression equation } & \multirow{2}{*}{$\mathrm{CV}(\%)$} \\
\hline & 0.0 & 0.4 & 0.8 & 1.2 & & \\
\hline $\mathrm{DMD}^{\mathrm{a}}$ & 33.88 & 42.53 & 50.03 & 54.25 & 1 & 6.42 \\
\hline OMD & 36.27 & 44.95 & 51.82 & 56.17 & 2 & 6.31 \\
\hline CPD & 28.91 & 39.45 & 48.62 & 51.28 & 3 & 11.38 \\
\hline EED & -6.62 & 17.29 & 38.78 & 45.87 & 4 & 24.31 \\
\hline NDFD & 36.38 & 37.29 & 37.25 & 37.30 & $\hat{\mathrm{y}}=37.06, \mathrm{~ns}^{\mathrm{b}}$ & 7.19 \\
\hline ADFD & 27.06 & 22.22 & 22.96 & 21.54 & $\hat{\mathrm{y}}=19.13, \mathrm{~ns}$ & 19.13 \\
\hline TCD & 39.09 & 47.18 & 52.81 & 57.39 & 5 & 5.67 \\
\hline $\mathrm{TDN}(\%$ of $\mathrm{MS})$ & 32.82 & 41.78 & 49.48 & 53.67 & 6 & 6.79 \\
\hline $\mathrm{DE}\left(\mathrm{Mcal} \mathrm{kg} \mathrm{MS}{ }^{-1}\right)$ & 1.45 & 1.70 & 2.04 & 2.26 & 7 & 9.16 \\
\hline
\end{tabular}

${ }^{\mathrm{a}} \mathrm{DMD}=$ Dry matter digestibility; OMD = Organic matter digestibility; CPD = Crude protein digestibility; $\mathrm{EED}=$ Ether extract digestibility; NDFD = Neutral detergent fibre digestibility; ADFD = Acid detergent fibre digestibility; TCD = Total carbohydrate digestibility; TDN = Total digestible nutrients; and $\mathrm{DE}=$ Digestible energy.

${ }^{\mathrm{b}}$ Not significant, $\mathrm{P}>.05$

${ }^{1} \hat{\mathrm{y}}=34.88+17.15 \mathrm{x}, \mathrm{R}^{2}=0.89 ; \mathrm{P}<.0001$

${ }^{2} \hat{y}=37.32+16.64 x, R^{2}=0.87 ; P<.0001$

${ }^{3} \hat{y}=30.62+19.07 x, R^{2}=0.79 ; P<.0001$

${ }^{4} \hat{y}=-3.01+44.74 x, R^{2}=0.80 ; P<.001$

$$
\begin{aligned}
{ }^{5} \hat{y} & =40.04+15.13 x, R^{2}=0.87 ; P<.0001 \\
6 \hat{y} & =33.90+17.56 x, R^{2}=0.88 ; P<.0001 \\
{ }^{7} \hat{y} & =1.44+0.69 x, R^{2}=0.79 ; P<.0001
\end{aligned}
$$

This result demonstrates the benefit of this feeding strategy, especially for the drier periods of the year, which by allowing a greater supply of nutrients to rumen microorganisms, provides an improvement in the rumen fermentation parameters, thereby increasing digestibility of nutrients for the total diet.

When the digestibility coefficients of both dry and organic matter are considered for the non-supplemented animals, it can be seen that these were well below the $60 \%$ threshold for diets of satisfactory nutritional value, but seem to be characteristic of the dry season in the caatinga, as verified by Formiga et al. (2011), an average of $37.82 \%$ for the in vitro digestibility of dicotyledons and other grasses.

The adoption of feed supplementation resulted in a positive linear effect $(\mathrm{P}<.05)$ on the digestibility of crude protein (CPD), 
with an increase of $19.07 \%$ in CPD per level of supplementation (Table 5).

This rise in CPD with feed supplementation demonstrates the importance of adopting this strategy for finishing goats on caatinga during the dry season. When relating the NDIP content of $44.05 \%$ from dry matter in the extrusa (Table 3) with the intake of crude protein from the pasture of $37.22 ; 37.59 ; 35.13$ and $30.73 \mathrm{~g}$ animal $^{-1}$ day $^{-1}$, respectively for those animals supplemented with 0.0 ; $0.4 ; 0.8$ and $1.2 \% \mathrm{BW}$, only $16.40 ; 16.56$; 15.47 and $15.54 \mathrm{~g}$ of $\mathrm{CP}$ are seen to be available for digestion and metabolism, with the possible impairment of animal performance.

The NDFD and ADFD were on average 37.06 and $19.13 \%$ respectively, and were not influenced $(\mathrm{P}>.05)$ by the levels of feed supplementation (Table 5). In this situation, feed supplementation was not effective with relation to the increase in NDFD, because even with the increase in DM intake from the supplement as a result of the substitution effect, NDF intake from the pasture still represented $88.1 ; 77.5$ and $66.9 \%$ of the total NDF intake for the diet, at levels of $0.4 ; 0.8$ and $1.2 \%$ respectively, thereby leading to the intake of a significant amount of NDF from the caatinga pasture containing high levels of lignin (Table 3 ).

The concentrations of digestible energy found in the non-supplemented animals express the energy content of the pasture. The low values for the animals under this treatment therefore show the importance of adopting supplementation, since pasture alone would not be able to meet daily energy requirements, which according to the NRC (2007) would be 1.70 Mcal digestible energy day ${ }^{-1}$, thus requiring a higher DM intake, which would however be limited by the low quality of the pasture.

The performance parameters of final body weight (FBW), total gain (TG) and average daily gain (ADG) were influenced $(\mathrm{P}<.05)$ by the levels of feed supplementation (Table 6), which resulted in a positive linear effect $(\mathrm{P}<.05)$ on the FBW, TG and ADG: an increase of 2.60; 3.09 and $0.036 \mathrm{~kg}$ per percentage point of each additional level of supplement.

Table 6. Mean values and regression equations for performance parameters of crossbred goats finished on a pasture of caatinga and receiving feed supplementation

\begin{tabular}{lcccccr}
\hline \multirow{2}{*}{ Parameter } & \multicolumn{9}{c}{ Level of supplementation $(\% \mathrm{BW})$} & \multirow{2}{*}{ Regression equation } & \multirow{2}{*}{ CV (\%) } \\
\cline { 2 - 5 } & 0.0 & 0.4 & 0.8 & 1.2 & & 12.89 \\
& 19.21 & 18.69 & 18.51 & 18.61 & $\hat{\mathrm{y}}=18.76, \mathrm{~ns}^{\mathrm{b}}$ & 14.63 \\
IBW $(\mathrm{kg})$ & 18.93 & 19.50 & 20.11 & 22.19 & 1 & 28.73 \\
FBW $(\mathrm{kg})$ & -0.286 & 0.808 & 1.597 & 3.571 & 2 & 28.77 \\
TG $(\mathrm{kg})$ & -0.003 & 0.010 & 0.018 & 0.041 & 3 & ADG $(\mathrm{kg})$ \\
\hline
\end{tabular}

${ }^{\mathrm{a}} \mathrm{IBW}=$ Initial body weight; FBW = Final body weight; $\mathrm{TG}$ = Total gain; and ADG = Average daily gain.

${ }^{\mathrm{b}}$ Not significant, $\mathrm{P}>05$.

${ }^{1} \hat{y}=18.6241+2.5961 x, R^{2}=0.70 ; P<.0260$

${ }^{2} \hat{y}=-0.4313+3.0896 x, R^{2}=0.65 ; P<.0001$

${ }^{3} \hat{y}=-0.0049+0.0356 x, R^{2}=0,65 ; P<.0001$ 
The reduced weight gain found in this research in the non-supplemented animals is directly related to the parameters of intake and digestibility, since the IDM, up to a supplementation level of $0.8 \% \mathrm{BW}$, was below the threshold required for maintenance and growth of $480 \mathrm{~g}_{\text {animal }}{ }^{-1}$ day $^{-1}$ (NRC, 2007). The low dry matter intake, together with the low CPD (28.91\%) and reduced amount of DE (1.45 Mcal kg DM ${ }^{-1}$ ) (Table 5), can therefore justify the weight loss (- 0.286 $\mathrm{kg}$ ) in those goats kept only on caatinga pasture.

Besides these factors, feed supplementation as formulated in this research, to meet an ADG of $50 \mathrm{~g}$ in those animals kept at the highest level of feed supplementation, may have been a determining factor in performance, as the ADG of animals kept at the highest level of supplementation was $0.009 \mathrm{~kg}$ less than that established for gain. These results emphasise the importance of feed supplementation during the dry season as an alternative to minimise weight loss, since such a feeding strategy allows better utilisation of the total diet.

In assessing the use of feed supplementation in $\mathrm{F} 1$ goats (Boer $\mathrm{x}$ SRD) finished on a pasture of caatinga, Carvalho Júnior et al. (2011) found a positive linear increase $(\mathrm{P}<.05)$ for total gain and average daily gain, with increases of $2.88 \mathrm{~kg}$ and $0.034 \mathrm{~kg} \mathrm{day}{ }^{-1}$ respectively, as a result of feed supplementation levels, but which were lower than those found in this study (Table 6), even though using supplementation levels of 0.0 to $1.5 \% \mathrm{BW}$, higher than those used here.

Feed supplementation increases the intake and digestibility of total dry matter and nutrients, giving an increase in the levels of total digestible nutrients and digestible energy from the diet, a fact that makes greater performance possible, with a recommendation for its use up to a level of $0.7 \%$ of body weight, without compromising the intake of pasture.

\section{REFERENCES}

ANDRADE, A.P.; COSTA, R.G.; SANTOS, E.M.; SILVA, D.S. Produção animal no semiárido: o desafio de disponibilizar forragem, em quantidade e com qualidade, na estação seca. Tecnologia e Ciência

Agropecuária, v.4, n.4, p.01-04, 2010.

CARVALHO JÚNIOR, A.M.; PEREIRA

FILHO, J.M.; SILVA, R.M.; SILVA, A.M.A.; CEZAR, M.F. Effect of supplementation on the performance of $\mathrm{F} 1$ crossbred goats finished in native pasture.

Revista Brasileira de Zootecnia, v.40, n.11, p.2510-2517, 2011.

COSTA, R.G.; ALMEIDA, C.C.; PIMENTA FILHO, E.C.; HOLANDA JUNIOR, E.V.; SANTOS, N.M. Caracterização do sistema de produção caprino e ovino na região semi-árida do estado da Paraíba. Brasil. Archivos de Zootecnia, v.57, n.218, p.195-205, 2008.

FORMIGA, L.D.A.S.; PEREIRA FILHO, J.M.; OLIVEIRA, N.S.; SILVA, A.M.A.; CÉZAR, M.F.; SOARES, D.C. Valor nutritivo da vegetação herbácea de caatinga enriquecida e pastejada por ovinos e caprinos.

Revista Brasileira de Saúde e Produção Animal [online], v.12, n.2, p.403-415, 2011.

GOMES, J.C.; OLIVEIRA, G.F. Análises

físico-químicas de alimentos. Viçosa, MG:

Universidade Federal de Viçosa, 2011. 303p.

INSTITUTO BRASILEIRO DE GEOGRAFIA E ESTATÍSTICA (IBGE). Pesquisa Pecuária Municipal, Rio de Janeiro, v.37, p.1-55, 2009. Disponível em: $<$ http://www.ibge.gov.br/home/estatistica/eco nomia/ppm/2009/ppm2009.pdf>. Acesso em: 17 maio 2013. 
Rev. Bras. Saúde Prod. Anim., Salvador, v.17, n.3, p.484-496 jul./set., $2016 \quad$ http://www.rbspa.ufba.br ISSN 15199940 http://dx.doi.org/10.1590/S1519-99402016000300014

LABORATÓRIO DE METEOROLOGIA DE PERNAMBUCO (LAMEPE).

Climatologia. Disponível em: $<$

http://www.itep.br/LAMEPE.asp $>$. Acesso em: 20 jul. 2011.

\section{NATIONAL RESEARCH COUNCIL -} NRC. Nutrient requirements of small ruminants: sheep, goats, cervids, and new world camelids. Washington, D.C.: National Academy Press, 2007. 362p.

SALIBA, E.O.S.; SILVA, F.A.E.; SILVA, C.R.M.E.; RODRÍGUEZ, N.M.; BARBOSA, G.S.S.C.; BORGES, A.L.C.C.; BORGES, I.; GINÇALVES, L.C.; JAYME, D.G.; SALIBA, J.S. Utilization of markers LIPE and $\mathrm{TiO} 2$ compared to total collection of feces on determination of digestibility and fecal output in bovines. Animal Production Science, v.30, p.125, 2014.

SANTANA, D.F.Y.; LIRA, M.A.; SANTOS, M.V.F.; FERREIRA, M.A.; SANTOS, D.C.; MELLO, A.C.L.; DUBEUX JÚNIOR, J.C.B.; ARAUJO, G.G.L. Consumo de matéria seca e desempenho de novilhas das raças Girolando e Guzerá sub suplementação na caatinga, na época chuvosa, em Pernambuco, Brasil.

Revista Brasileira de Zootecnia, v.39, n.10, p.2148-2154, 2010.

SANTOS, G.R.A.; BATISTA, A.M.V.; GUIM, A.; SANTOS, M.V.F.; MATOS, D.S.; SANTORO, K.R. Composição química e degradabilidade in situ da ração em ovinos em área de caatinga no sertão de Pernambuco. Revista Brasileira de Zootecnia, v.38, n.2, p.384-391, 2009.

SANTOS, G.R.A.; BATISTA, A.M.V.; GUIM, A.; SANTOS, M.V.F.; SILVA, M.J.A.; PEREIRA, V.L.A. Determinação da composição botânica da dieta de ovinos em pastejo na caatinga. Revista Brasileira de Zootecnia, v.37, n.10, p.1876-1883, 2008.
SILVA, D.C.; GUIM, A.; SANTOS, G.R.A.; MESQUITA, F.L.T.; MORAIS, N.A.P.; URBANO, S.A.; MOREIRA FILHO, M.A.; LAFAYETTE, E.A. Níveis de suplementação alimentar sobre as características quantitativas da carcaça e composição tecidual do pernil de caprinos mestiços terminados na caatinga.

Revista Brasileira de Saúde e Produção Animal [online], v.15, n.3, p.705-716, 2014.

SOARES, L.F.P.; GUIM, A.; FERREIRA, M.A.; MODESTO, E.C.; BATISTA, A.M.V.; MONTEIRO, P.B.S. Assessement of indivators and collection methodology to estimate nutrient digestibility in buffaloes. Revista Brasileira de Zootecnia, v.40, n.9, p.2005-2010, 2011.

SNIFFEN, C.J.; O'CONNOR, J.D.; VAN SOEST, P.J.; FOX, D.G.; RUSSELL, J.B. A net carbohydrate and protein system for evaluating cattle diets: II Carbohydrate and protein availability. Journal of Dairy

Science, v.70, n.11, p.3562-3577, 1992.

SAS. Statistical Analysis SYSTEM. SAS/STAT User's Guide. Cary, NC: SAS Institute, 2001.

Data de recebimento: 10/11/2015

Data de aprovação: 07/06/2016 